\title{
Interruptions of Men and Women in Selected Debates of Al-Jazeera Arabic Channel: A Pragmatic Analysis of the Opposite Direction
}

\author{
Raeda Tartory ${ }^{1}$ \\ ${ }^{1}$ Faculty of Arts and Sciences, Al-Ahliyya Amman University, Amman, Jordan \\ Correspondence: Raeda Tartory, Faculty of Arts and Sciences, Al-Ahliyya Amman University, Amman, Jordan. \\ E-mail: r.tartory@gmail.com
}

Received: November 29, 2018 Accepted: December 27, 2018 Online Published: March 2, 2019

doi:10.5539/ijel.v9n2p273 URL: https://doi.org/10.5539/ijel.v9n2p273

\begin{abstract}
The present study aims to explore the gender patterns during interruptions in the context of political television discussions in the Arab community. Five mixed-sex episodes of the well-known program "The Opposite Direction" presented on Al-Jazeera Channel were examined. Quantitative and qualitative analyses were carried out to determine, which gender did more interruptions than the other. The study has considered each gender to use verbal and non-verbal statements to express that they were doing interruptions or that they were being interrupted. The results showed that women interrupted more than did men. Moreover, it has also been shown that men reacted in a more severe and aggressive way, when they were interrupted by women.
\end{abstract}

Keywords: discussions, gender, gender patterns, interruptions, language, politics, television

\section{Introduction}

The unstable political situation of the Middle East has increased the number of viewers of political television discussions (PTDs) in the last two decades. Al-Jazeera TV channel is a famous news channel in the whole world as well as in the Arabic world. This channel has a very big impact on the industry of news media and has attracted attention of all Arab television viewers. One of the most popular PTD programs is called "Al Eteijah al Muakes", which means "The Opposite Direction" broadcasted on the Arabic channel, Al-Jazeera. This TD program tackles important current political and social issues of the Arabic community; although, most of the topics are politically-oriented. "The Opposite Direction" PTD is similar to panel discussions, in which a discussion about a certain topic is happening between some guests (most of the time two) and a host mediating between them. The invited guests are people having a good knowledge of the topic of the episode they are participating in. Knowledge about a certain topic is a source that influences the distribution of power in an interaction (Holmes, 1995, p. 17). Though this PTD has been broadcasting for more than twenty years, any a frequent observer of the show notices the small participation of women in comparison to men.

A new episode of this program is presented every week. The same male host present all episodes. In each episode, there are two guests that are usually males most of the time or one male and one female on rare times, but never two females. This raises matters about the participation of women in the media in general and on such TDs in particular. One important question that comes to mind is about the conversational behavior of those women. In other words, does women's less participation affect their way of talking? And if yes, does their way of talking lead to viewing them less powerful than men in this context?

"The Opposite Direction" possesses a unique discourse characteristic as the guests are invited to this PTD to talk about totally opposite views related to the topic, and this is indicative in the name of this PTD (The Opposing Direction). The guests use interruptions as a way to contribute more to the topic, to disagree, and to convince the host and the television viewers of their own views for each guest to prove his/her view as the only right view over the other guest's view. Interruptions of this kind signal power of their users and help them dominate an interaction (Holmes, 1995). The present study has tried to fill a gap in the literature by analyzing interruptions made by men and women guest participating on these PTDs, since language and gender is under-investigated in the Arabic-speaking communities in general and in this context of PTD in particular. The questions addressed by this study are as follows;

- Which gender interrupts more than the other? 
- How each gender expresses doing interruption and reacts to being interrupted on these Arabic PTDs?

\section{Gender-Related Patterns in Interruptions}

One widely cited finding in language and gender research is that generally and overwhelmingly men interrupt women more than the reverse. Zimmerman and West (1975) found that men interrupted women regularly in mixed-sex interactions. Other studies have also narrated that men are more likely to interrupt others, as compared to women (Eakins \& Eakins, 1976; Holmes, 1995; Leet-Pellegrini, 1980). Further evidence comes from studies investigating interruptions in television and radio settings. Edelsky and Adams (1990) studied television debates in the United States and found that males tended to dominate the discussions by violating the rules of the debate to gain the floor more often as compared to their female counterparts. Kotthoff (1997) also examined Austrian television discussions and found that invited male experts negotiated and achieved high expert status for themselves more often than did invited female experts. Mullany (1998) analyzed political and non-political interviews from BBC Radio Four and found that men generally talked in competitive ways; while, women interacted more in cooperative ways. Studies have also found gender to be more powerful than status for determining interruptions in mixed-sex conversations. A study conducted by Woods (1989) to analyze the conversations between work colleagues showed that males of low occupational status interrupted their female superiors more often than the reverse. Likewise, West (1998) showed that male doctors interrupted their patients more than their patients interrupted them; while, the male patients interrupted more frequently than the female doctors.

James and Clarke (1993) reviewed many studies on gender and interruptions and found conflicting findings. Their survey claimed that the there was no difference between men and women regarding interruptions, and that some studies show men interrupting more than women (Beattie, 1981; James \& Clarke, 1993; Leet-Pellegrini, 1980; West \& Zimmerman, 1983). On the contrary, other studies showed that women interrupted more as compared to men (James \& Clarke, 1993; Kennedy \& Camden, 1983; Murray \& Covelli, 1988). These studies revealed that knowledge about the topic of discussion increases the occurrences of interruptions of both genders in conversations. James and Clarke (1993) showed that women interrupted more than or as much as men when the topics of conversation were about areas of expertise for those women (Courtright, Millar, \& Rogers - Millar, 1979; Shaw \& Sadler, 1965).

The above conflicting findings are attributed mainly to the inconsistency in the methodology and definition of what an interruption means. Previous studies have identified interruptions from different perspectives (Beattie, 1983; Bilmes, 1997; Murray, 1985; Talbot, 1992; Zimmerman \& West, 1975). For instance, Zimmerman and West (1975) only counted the number of occurrences of interruptions; while, Beattie (1983) identified interruptions in relation to their context. Finally, interruptions, as any other linguistic feature, are socially and culturally relative and context-sensitive. The Finns were found to prefer one person only talking at a particular time (Stubbe, 1998).

However, Al-Rojaie (2003) compared interruptions in Arabic panel news interviews to those in English panel news interviews and found that Arabic-speaking participants used interruptions more than double the frequency of English-speaking participants. None of the previous studies have been conducted to compare interruptions and gender of Arabic speakers. The present study seeks to find out if both genders would interrupt equally as they are equal in terms of their knowledge of the topic they are talking about.

\section{Definition of Interruption}

Interruptions are linguistic devices that depend on how and when interactants take turns. An interruption happens when an interactant starts speaking before the current speaker completes his talk at turn (James \& Clarke, 1993). Interruptions are either simultaneous (the interrupter initiates talk while the current speaker is still talking) or 'silent' (the interrupter starts during a short pause in the interruptee's turn with no simultaneous speech). Following Anderson and Leaper (1998), interruptions in this research are intrusive. Intrusive interruptions (IIs) are ones that interfere in another's talking turn and are used to dominate the other (Karakowsky, McBey, \& Miller, 2004). However, IIs happen when the interrupter succeeds in disturbing the talk of the interruptee before he/she completes his/her utterance, i.e., before reaching a transition relevance place (a point that indicates the completion of a turn). To situate interruptions in this special speech event (PTDs), they are intrusive because they violate the speaking rights of the one speaking and attempt at stealing the turn (Bilmes, 1997). Factors related to context of the interruption are taken into considerations. Examples of such factors are the content of the interruption (James \& Clarke, 1993) including its effects on the subsequent interaction (Shaw, 2002).

The study also uses the participant-oriented approach (how participants 'do interruption' and 'do being interrupted') presented by Bilmes (1997) as a further indication of the occurrence of interruption. The interrupter 
and the interruptee utter explicit or implicit verbal or non-verbal signals that show the violation of the interruptee's speaking rights. In doing interruption, interrupters request permission to interrupt, as in can I just interrupt, or by apologizing for the interruption, as in I hate to interrupt, but (ibid.). On the contrary, in doing being interrupted, the ones interrupted show that their turns have been interrupted inappropriately with the use of three major ways: direct claims, interruption displays, and ignoring.

Direct claims are the most explicit method used to convey that they are being interrupted, as when they say let me finish this, I can't unless you let me finish, and you keep interrupting me (ibid.). Interruption displays refer to the different verbal and non-verbal utterances, which interactants use to demonstrate their annoyance and their insistence on keeping the floor through using facial expressions, gestures, grammatical devices, repetition, and raised voice. When ignoring (the third method mentioned above), the interrupted participant ignores what the interrupter has said completely indicating that the interruption is illegal.

\section{Methodology}

\subsection{Data Collection}

The data for this study consists of five mixed-sex video-recorded episodes of "The Opposite Direction" program broadcasted on Al-Jazeera channel. Data collection for this study was initiated in May 2017. All the episodes of this PTD from May 2017 and backwards to the beginning of 2011 were viewed and only five mixed-sex episodes were found. In the year 2012, there were no mixed-sex episodes at all, and the same female guest appeared on more than one episode of this PTD during this examined time. Only one mixed-sex episode with the same female guest was analyzed to arrive at some objective generalizations. These episodes were downloaded from the archive of Al-Jazeera channel website (www.aljazeera.net), which saved time and effort and provided a clear picture of the equity of participation of men and women on these PTDs.

Only interruptions of guests are analyzed. Guests were equal in terms of their knowledge about the topic under discussion, and that they belong to the same general age group as they have started career. They were presumed to be above the age of 30 years, which minimized variation in factors other than gender. There were no studio audiences on these PTDs; therefore, the variable of audience influence was removed. Interruptions performed by the host were not analyzed in this study as they are part of their job to control the discussion and they do not fall within the interest of this study. Table 1 has presented a summary of the Arabic PTDs analyzed in this research. All these episodes were presented by the same male host, and each had two guests; one male and one female.

Table 1. Summary of the Arabic television discussions

\begin{tabular}{|c|c|c|}
\hline \multicolumn{3}{|c|}{ PTDs under study } \\
\hline No. of episode & Date of broadcasting & Name of episode \\
\hline \multirow[t]{2}{*}{1} & $21-2-2017$ & هل مازال سلاح حزب الله ضد اسرائيل؟ \\
\hline & & Is the weapon of Hizeb Allah still against Israel? \\
\hline \multirow[t]{2}{*}{2} & $31-1-2017$ & روسيا محل ترحيب عربي أم مستعمر؟ \\
\hline & & Is Russia welcomed by Arabs or is it a colonizer? \\
\hline \multirow[t]{2}{*}{3} & $17-1-2017$ & هل كانت الثورة نعمة أم نقمة على تونس؟ \\
\hline & & Was the revolution a blessing or a curse for Tunisia? \\
\hline \multirow[t]{2}{*}{4} & 22-11-2016 & لماذا يراهن بعض السوريين على ترامب؟ \\
\hline & & Why some Syrians are betting on Trump? \\
\hline \multirow[t]{2}{*}{5} & $25-10-2011$ & البحرين.... انتفاضة شعبية ام صراع سياسي؟ \\
\hline & & Bahrain.... a public uprising or a political conflict? \\
\hline
\end{tabular}

The talk is converted into a written form using standard orthography, a process known as transcription (Cameron, 2001) to analyze interruptions. However, transcription was only a research tool used to represent talk, but video-tapes constitute the data for this research (Coates \& Thornborrow, 1999). Transcriptions were first provided in the Arabic language, then translated into English. Only the translated transcriptions in English language are provided as examples. The convention used for the identification of an interruption is a slash (/) immediately after the interrupted part as proposed in the HIAT system, separated by a space before and after the slash. The abbreviations used to save space and identify the gender of the guests on the PTDs are as follows:

- $\quad$ MG stands for Male Guest

- $\quad$ FG for Female Guest.

Finally, the first line of each score is given to the main speaker (the one holding the floor). Example has been 
provided as follows:

FG: expanding the participation through organizations and not through /

MG: Where is that on the ground?

\subsection{Method of Analysis}

Quantitative and qualitative analyses were used to answer the research questions, as advised by Holmes and Meyerhoff (2003, p. 15). Number of interruptions and their percentage of occurrence for each gender group (male guests, and female guests) were provided. Afterward, a detailed description and interpretation of some examples of how guests of both genders "do interruptions" and "do being interrupted" are given to display how power derived from their knowledge of the topic is carried out through their interruptions. Only the first thirty minutes of each episode were analyzed to allow intensive qualitative interruptions.

\section{Findings and Discussion Related to Interruptions}

\subsection{Gender Patterns of Intrusive Interruptions}

In terms of quantifications, female guests made more IIs than did male guests appearing on the analyzed PTDs. Table 2 has shown that the number of IIs made by male guests in all PTDs is $(\mathrm{n}=20)$ interruptions, accounting for $(41.7 \%)$ percent of all IIs performed by both genders. The number of IIs made by female guests was $(\mathrm{n}=28)$, accounting for $(58.3 \%)$ percent of all IIs performed by both genders.

Table 2. Number of intrusive interruptions performed by each gender in the PTDS

\begin{tabular}{|c|c|c|}
\hline Name of PTDS & No. of interruptions by MGs & No. of interruptions by FGs \\
\hline هل مازال سلاح حزب الله ضد اسرائيل؟ & 4 & 4 \\
\hline \multicolumn{3}{|l|}{ Is the weapon of Hizeb Allah still against Israel? } \\
\hline روسيا محل ترحيب عربي أم مستعمر؟ & 2 & 2 \\
\hline \multicolumn{3}{|l|}{ Is Russia welcomed by Arabs or is it a colonizer? } \\
\hline هل كانت الثورة نعمة أم نقمة على تونس؟ & 9 & 15 \\
\hline \multicolumn{3}{|l|}{ Was the revolution a blessing or a curse for Tunisia? } \\
\hline لماذا يراهن بعض السوريين على ترامب؟ & 0 & 0 \\
\hline \multicolumn{3}{|l|}{ Why some Syrians are betting on Trump? } \\
\hline البحرين.... انتفاضة شعبية ام صراع سياسي؟ & 5 & 7 \\
\hline \multicolumn{3}{|l|}{ Bahrain.... a public uprising or a political conflict? } \\
\hline $\begin{array}{l}\text { Total number of intrusive interruptions performed by each } \\
\text { gender in all PTDs }\end{array}$ & 20 & 28 \\
\hline
\end{tabular}

The gender-related patterns of IIs found in this study were in opposition to gender patterns revealed by the majority of studies investigating interruptions in English-speaking communities in various contexts. Majority of the studies have stated that males interrupt females more than the opposite (Eakins \& Eakins, 1976; Holmes, 1995; Leet-Pellegrini, 1980; West \& Zimmerman, 1983). Furthermore, Zimmerman and West (1975) in the United States, Woods (1989) in the United Kingdom, Holmes (1995) in Australia, and Sapabsri, Dhanesschaiyakupta, Thep-Ackrapong, and Phimswat (2018) in Thailand revealed that men interrupt more than women. Even in the context of television and radio settings, which is similar to the context of PTDs, studies found that males tend to interrupt more than females (Edelsky \& Adams, 1990; Kotthoff, 1997; Mullany, 1998).

However, the result of this study stated that the women guests appearing on the analyzed PTDs interrupted more than did the male guest is still in consistent with the findings of some studies done mainly on English-speaking communities. For example, women were found to interrupt more than or as much as men when the topics of conversation revolved around areas of expertise for those women (Courtright et al., 1979; James \& Clarke, 1993; Shaw \& Sadler, 1965). Other studies (James \& Clarke, 1993; Kennedy \& Camden, 1983; Murray \& Covelli, 1988) found women generally interrupting more than men.

Evidence from this study seems to suggest that knowledge gave women confidence to interrupt more than men to contribute more and direct the topic in favor of their point of view at least in the context of the PTDs in Arabic-speaking communities. An example of women's frequent IIs in the data under study can be seen in the PTD "Was the revolution a blessing or a curse for Tunisia?" The following extract shows how the female guest interrupted the flow of the male guest's turn many times to disagree with him and prove her opposite view on the topic. The male guest talks about the advantages of the revolution in Tunisia and he mentions that the independence of the elections of judges after the revolution. The female guest, who is an opponent to the 
revolution, interrupts the male guests many times until she succeeds in taking over the floor. At the beginning, she cuts the turn of the male guest to mention that there are problems associated with the superior committee of justice. And then, she interrupts to question how the association of judges is accusing authorities and asking for repairs. The female guest keeps disturbing the talk of the male guest until she succeeds in taking over the floor from him.

[Topic: The revolution in Tunisia and the opposite revolution]

MG: What my colleague refused to call a revolution was a revolution, the political change that

MG: happened in Tunisia happens only through revolutions, when you find Bin Ali in Saudi Arabia

MG: between prisons and exiles and you find his opponents ruling the state, this happens only

MG: by a revolution, I mean we are playing with concepts /

FG: Fuad Almbaseq in authority, Fuad in authority

MG: that was the choice of the Tunisian people /

FG: Fuad Almbaseq in authority

MG: not to take the revolution to the extreme / I mean, I...I...I am not surprised / one minute

FG: what prevented him, I am not against you

MG: one minute, I am surprised, you are criticizing the nonviolence

MG: of the Tunisian people, and that they did not go to the extreme, to violence, to blood,

MG: this the nature of the Tunisian people / Today, no one

FG: to choose Fuad Almbaseq

MG: interferes in the business of the Tunisian judge, no one appoints him,

MG: not the minister of justice, not the president of the country, not the wife of the president, not the

MG: cousin of the wife of the president / of course,

FG: today there is a problem with the Superior Committee of Justice

MG: of course, of course, of course, of course, of course, the judge is elected, the council

FG: there is a problem, the Judges' Association accuses, the Judges' Association asks for,

MG: is elected, and for sure this worries the opposing revolution, / and worries those

FG: and how does this worry them?

MG: who cannot imagine, eh, eh, but there is an opposing position to

MG: the syndicate of judges, I mean there is life in Tunisia, we were in a cemetery, today

MG: there is a disagreement inside judiciary, / there is a disagreement inside parties, and there are

FG: you are till today (not clear) you are till today

FG: isn't it shameful after six years there is an assessment for the period of Bin Ali with

MG: many parties, many parties in the media

FG: its advantages and disadvantages (continues)

\subsection{Gender Patters in Relation to the Participant-Oriented Approach}

The present study has used the participant-oriented approach offered by Bilmes (1997) as a further indication and affirmation of the occurrence of a particular case of interruption. This approach emphasizes the importance of the participants' expressions (verbally and non-verbally) relating to the violation of their speaking rights resulting from interruptions. Bilmes (1997) noted that speakers as well as listeners are more likely to refer or object to the occurrence of interruptions in political debates than in other types of speech events. Following is the first method men and women use to point out the occurrence of an interruption.

\subsubsection{Doing Interruptions}

"Doing interruptions" was not used at all by both genders on the PTDs under study. There were some factors that might explain the non-use of this method by men and women guests participating on these PTDs. First, the name of the program is the "Opposite Direction" and the analyzed PTDs are political in nature. Guests are trying by all 
means to interrupt each other to emphasize their different views on the topic of discussion. Doing interruption involves a verbal recognition, on the part of the interrupter. The one making the interruption might apologize to mitigate the effect of the violation of the interruption. Bilmes (1997) found English-speaking participants using "doing interruptions" in political debates, and that Arabic-speaking participants did not perform any "doing interruptions" on the PTDs suggested that Arabs were less concerned than English speakers about violating others' speaking rights through interruptions.

\subsubsection{Doing Being Interrupted}

Doing being interrupted is very different from doing interruptions. In doing interruptions, the interrupter admits the violation of speaking right of the interrupttee. On doing being interrupted, the one interrupted objects to the violation of his/her speaking rights caused by the interrupter. There are three ways by which participants do being interrupted, and they are: (1) direct claims, (2) interruption display, and (3) ignoring. Following is a discussion of the use of each one of these methods by both genders on the PTDs under study.

\subsubsection{Direct Claims}

Direct claims are explicit verbal expressions uttered by someone talking to show their annoyance and disapproval of another co-participant's talk before they have finished their own turns. Men and women on the analyzed PTDs used almost the same number of direct claims to point out that they were illegally interrupted. However, by examining the content of these direct claims and their context, there is some evidence to suggest that direct claims used by men guests were more severe that the ones used by female guests. Following are examples of direct claims as used by men and women on the PTDs under study.

The following extract comes from the episode "Is Russia welcomed by Arabs or is it a colonizer?" and shows how the female guest insists on keeping her turn to finish what she is talking about. When the male guest interrupted her to disagree with her, the female guest objects to this interruption by saying "Let me finish Mr. Mohammad, I did not interrupt you, please" as a direct claim. What is noticeable is the use of polite terms "Mr." and "please" by this female guest while making this direct claim.

[Russia's interference in Syria]

FG: The world is in need of an international system with multiple poles and not only one possessed

FG: by one power controlling the destiny of the world according to its narrow interests, and then

FG: expanding the participation through organizations and not through /

MG: Where is that on the ground mam?

MG: where is that from the mascaras on the ground mam, where is that from slaughtering

FG: Let me finish Mr. Mohammad, I did not interrupt you, please Mr. Mohammad

MG: Syrians, where is that, this reminds me of the style of Bin Ali who wrote on the

FG: I did not interrupt you

MG: "safe deposit" of robbery "work well because your work will be seen by the Lord, the prophet

MG: and the believers" all tyrants write constitutions of freedom

On the contrary, male guests used direct claims in a more severe way in terms of their content and in terms of the way they were uttered with. For example, when the female guest interrupted the male guest in the following extract from the episode "Bahrain.... a public uprising or a political conflict?", the male guest objects by saying "I am talking, I am talking, I am talking" several times in a loud voice and harsh manner to stop the female guest from talking further.

[Iran and democracy in Bahrain]

MG: I tell you, the problem is that we say Iran wants and Hizb Allah wants, I tell you that the people

MG: of Bahrain wants, you are saying Iran wants, let Iran want what it wants, it is up to them, /

FG: You do not represent the people of Bahrain,

MG: I am talking, I am talking, I am talking (in a loud voice)

FG: and it is not the people of Bahrain that wants, you should know

MG: 350 thousand and I will put 350 thousand more and go for referendum (continues)

FG: that there are 350 thousand Bahraini who went out against this. 
A further support of the severity of the direct claims used by men comes from the episode "Was the revolution a blessing or a curse for Tunisia?" When the female guest interrupted the male guest, he objected with a severe aggressive direct claim by saying to her "it is unbelievable that you raise an idea for me to answer, and then you answer instead of me.

[Tunisia after the revolution]

MG: The corruption you are talking about was protected from the regime, and the

MG: international bank / excuse me, excuse me, excuse me, okay then, you raise an idea

FG: I did not say, the president, the president of the corruption authority is

MG: for discussion and then you want to discuss the idea yourself, I understand this woman,

FG: the one who said

MG: her view is totally wrong (continues)

FG: It is not my opinion, it is not my opinion

\subsubsection{Interruption Displays}

Interruption displays are used by both sexes on the PTDs under study. The analysis showed no gender-related patterns towards using this method. Further, they are the least used method by both genders to show their refusal for being interrupted. The interruption displays used by men and women on these PTDs included repetition, using a loud voice, and stopping talking for a short time in a way that shows objection and denial to being interrupted.

\subsubsection{Ignoring}

The last method interrupttees use to "being interrupted" is ignoring. Bilmes (1997, p. 520) pointed out that "ignoring someone is perhaps the sincerest form of insult—and, in the realm of manners, the deepest cut of all-but it can be used to express disapprobation as well as contempt". Men guests performed more ignoring than did female guests on the analyzed PTDs. Therefore, evidence from this seems to suggest that at least in this televised context, men knowledgeable on Arabic PTDs try to exercise dominance and power over women by using "ignoring" to their interruptions.

In the following extract from "Bahrain.... a public uprising or a political conflict?", the female guest interrupted the male guest, who was in the middle of his turn to disagree and challenge what he is saying. The male guest did not stop talking and instead he showed his refusal for this female interruption by completing his talk as if there was no interruption. Actually, this male used the three ways of "doing being interrupted" through using a direct claim (I did not interrupt), along with using an interruption display (by repeating some parts of what he is saying) and continuing talking with no stopping at all.

[Democratic demands in Bahrain and the media]

MG: Those swords were not raised in the circle, but they were raised in the yard, if you want

MG: to say that there were swords, how many swords, the picture that appeared / and not those

FG: in hundreds, in in hundreds,

MG: faces, I did not interrupt, those were the flags of AL Qaeda

FG: they were carried by ambulance cars from one place to another, in hundreds

MG: in Bahrain and we are a state, we are an elected government and they say these are the

FG: swords were carried and in front of our eyes

MG: demands of few people (continues)

\subsection{Asking for Interruptions}

A unique type of interruptions appeared on the PTDs under study "asking for interruption". This type happens when the male guest who is speaking during his turn directs his talk to the female guest, and not the presenter. This is done in a provocative way that challenges the view of the female guest, usually in the form of a question. As she has been asked a question, the addressed female guest tries to interrupt to defend her view and answer the question. The interrupttee (the one who asked for the interruption) prevents the interrupter from interrupting instead of giving her the chance to answer the question; although, this interruption was a response to answer his question. The analysis of interruptions of the PTDs under study shows that male guests used this type of 
interruptions and it was not used by female guests. This type of interruption seems to suggest an exercise of power from powerful participants (males), over less powerful ones (females) in the PTDs. However, further examination for different types of heated discussions, similar to the PTDs under study, is needed before drawing any gender patterns related to the use of this type of interruptions. Following is an extract from the episode "Bahrain.... a public uprising or a political conflict?" illustrating this type of interruption.

[The constitution and democracy]

MG: There are simple concepts every sensible person understands, freedom, democracy,

MG: dignity, partnership, but a referendum, / where is that? One minute,

FG: You have all these things in Bahrain

MG: one minute please, it turned out that this constitution is still there (continues)

\section{Conclusion}

The present study has examined gender patterns in using intrusive interruptions and in the power displayed by each gender when they "do interruptions" and "do being interrupted". The well-known political television discussion program "The Opposing Direction" was chosen as the setting for this study. The interruptions of men and women guests (who are knowledgeable in the topic of discussion) in five mixed-sex episodes of this program were analyzed qualitatively and quantitatively.

The results showed that female guests performed more IIs than did male guests. One possible explanation for women's use of more intrusive interruption in this study might be their concern to contribute to the discussion and defend their own views; although, men's frequent use of intrusive interruptions in previous research was explained as a kind of dominance and exercising power over women. However, women's frequent use of intrusive interruptions is in agreement with research investigating interruptions and gender in conversation of topics women are knowledgeable in in Western societies. The results also showed that male guests reacted in a more severe way to "being interrupted", especially when using direct claims and ignoring. Further, male guests were found using a special kind of interruption "asking for interruption".

The study hopes to raise awareness of the interruption behavior of both genders in the Arabic-speaking communities in general and in political television discussions in particular. Both genders violated the speaking rights of each other, but each in a different way. People working on inviting people to such PTDs might inform guests of the possible outcomes of women using IIs frequently and of men reacting in an aggressive manner to being interrupted on the discussion in general. Equality in such discussions implies equality in the interrupting behavior of women and men whether in terms of number of interruptions or in terms of avoiding using hostile ways when being interrupted. More testing for this result is needed in different language communities across the world and in different contexts before any conclusions can be made because interruptions are socially relative and context-sensitive. Further investigation on this type of interruption is needed in Arabic and English communities, especially in heated political television discussion.

\section{Acknowledgements}

The author is very thankful to all the associated personnel in any reference that contributed in/for the purpose of this research.

\section{References}

Al-Rojaie, Y. I. (2003). A discourse analysis of interruption, moderator role, and address terms in Arab and American panel news interviews. Unpublished doctoral dissertation, Oklahoma State University, Oklahoma, USA.

Anderson, K. J., \& Leaper, C. (1998). Meta-analyses of gender effects on conversational interruption: Who, what, when, where, and how. Sex Roles, 39(3), 225-252. https://doi.org/10.1023/A:1018802521676

Beattie, G. W. (1981). Interruption in conversational interaction, and its relation to the sex and status of the interactants. Linguistics, 19(1-2), 15-36. https://doi.org/10.1515/ling.1981.19.1-2.15

Beattie, G. (1983). Talk: An analysis of speech and non-verbal behavior in conversation. Milton Keynes: Open University Press. https://doi.org/10.2307/414180

Bilmes, J. (1997). Being interrupted. Language in Society, 26(4), 507-531. https://doi.org/10.1017/S0047404500021035

Cameron, D. (2001). Working with spoken discourse. London: Sage. 
Coates, J., \& Thornborrow, J. (1999). Myths, lies and audiotapes: Some thoughts on data transcripts. Discourse and Society, 10(4), 594-597. https://doi.org/10.1177/0957926599010004015

Courtright, J. A., Millar, F. E., \& Rogers-Millar, L. E. (1979). Domineeringness and dominance: Replication and expansion. Communications Monographs, 46(3), 179-192. https://doi.org/10.1080/03637757909376005

Eakins, B., \& Eakins, G. (1976). Verbal turn-taking and exchanges in faculty dialogue. In B. Dubois \& I. Crouch (Eds.), The sociology of the languages of American women (pp. 53-62). San Antonio, Texas: Trinity University.

Edelsky, C., \& Adams, K. (1990). Creating inequality: Breaking the rules in debates. Journal of Language and Social Psychology, 9(3), 171-190. https://doi.org/10.1177/0261927x9093001

Holmes, J. (1995). Women, men and politeness. London: Longman.

Holmes, J., \& Meyerhoff, M. (2003). Different voices, different views: An introduction to current research. In J. Holmes \& M. Meyerhoff (Eds.), The handbook of language and gender (pp. 1-17). London: Blackwell Publishing. https://doi.org/10.1002/9780470756942.ch

James, D., \& Clarke, S. (1993). Women, men, and interruptions. In D. Tannen (Ed.), Gender and conversational interaction (pp. 231-280). Oxford: Oxford University Press.

Karakowsky, L., McBey, K., \& Miller, D. L. (2004). Gender, perceived competence, and power displays: Examining verbal interruptions in a group context. Small Group Research, 35(4), 407-439. https://doi.org/10.1177/1046496404263728

Kennedy, C. W., \& Camden, C. T. (1983). A new look at interruptions. Western Journal of Communication (includes Communication Reports), 47(1), 45-58. https://doi.org/10.1080/10570318309374104

Kotthoff, H. (1997). The interactional achievement of expert status: creating asymmetries by "Teaching conversational lectures" in TV discussions. In H. Kotthoff \& R. Wodak (Eds.), Communicating gender in context (vol. 42, pp. 78-139). Amsterdam: Benjamins. https://doi.org/10.1075/pbns.42.09kot

Leet-Pellegrini, H. (1980). Conversational dominance as a function of gender and expertise. In H. Giles, W. P. Robinson \& P. M. Smith (Eds.), Language: Social psychological perspectives (pp. 97-104). Oxford: Ergamon. https://doi.org/10.1016/b978-0-08-024696-3.50020-x

Mullany, L. (1998). Linguistic politeness and sex differences in broadcast interviews. Unpublished master's thesis. University of Leeds, Leeds, England.

Murray, S. O. (1985). Toward a model of members' methods for recognizing interruptions. Language in Society, 14(1), 31-40. https://doi.org/10.1017/s0047404500010927

Murray, S. O., \& Covelli, L. H. (1988). Women and men speaking at the same time. Journal of Pragmatics, 12(1), 103-111. https://doi.org/10.1016/0378-2166(88)90022-7

Sapabsri, O., Dhanesschaiyakupta, U., Thep-Ackrapong, T., \& Phimswat, O. (2018). An analysis of gender and status affecting conversational interruptions. PEOPLE: International Journal of Social Sciences, 4(1), 257 271. https://doi.org/10.20319/pijss.2018.41.257271

Shaw, M. E., \& Sadler, O. W. (1965). Interaction patterns in heterosexual dyads varying in degree of intimacy. The Journal of Social Psychology, 66(2), 345-351. Doi: https://doi.org/10.1080/00224545.1965.9919654

Shaw, S. (2002). Language and gender in political debates in the House of Commons. Doctoral dissertation. Institute of Education, University of London, London, UK. Retrieved from http://discovery.ucl.ac.uk/10019100/1/272259.pdf

Stubbe, M. (1998). Are you listening? Cultural influences on the use of supportive verbal feedback in conversation. Journal of Pragmatics, 29(3), 257-289. https://doi.org/10.1016/s0378-2166(97)00042-8

Talbot, M. (1992). 'I wish you'd stop interrupting me!': Interruptions and asymmetries in speakers-rights in equal encounters. Journal of Pragmatics, 18(5), 451-466. https://doi.org/10.1016/0378-2166(92)90084-o

West, C. (1998). When the doctor is a "lady": Power, status and gender in physician-patient encounters. In J. Coates \& P. Pichler (Eds.), Language and gender: A reader (pp. 396-412). Oxford: Blackwell Publishers. https://doi.org/10.1525/si.1984.7.1.87

West, C., \& Zimmerman, D. H. (1983). Small insults: A study of interruptions in cross-sex conversations between unacquainted persons. Language, Gender and Society, 102-117. 
Woods, N. (1989). Talking shop: Sex and status as determinants of floor apportionment in a work setting. In J. Coates \& D. Cameron (Eds.), Women in their speech communities (pp. 141-157). London and New York: Longman.

Zimmerman, D. H., \& West, C. (1975). Sex roles, interruptions and silences in conversation. In B. Thorne \& N. Henley (Eds.), Language and sex: Difference and dominance (pp. 105-129). Massachusetts: Newbury House Publishers. https://doi.org/10.1075/cilt.125.12zim

\section{Note}

The gist of this article was presented at the International Conference on Cultural Dialogue in Linguistics, Literature, and Translation held at Zarqa University, in Zarqa, Jordan, between November 14-15, 2018. For more information, please visit: www.apetau.com

\section{Copyrights}

Copyright for this article is retained by the author, with first publication rights granted to the journal.

This is an open-access article distributed under the terms and conditions of the Creative Commons Attribution license (http://creativecommons.org/licenses/by/4.0/). 